\title{
Importance of microhabitat characteristics in the macrobenthos microdistribution of a large river reach
}

\author{
M. Bournaud 1 \\ H. Tachet ${ }^{1}$ \\ A. Berly 1 \\ B. Cellot 1
}

Keywords : large river, Rhône River, macroinvertebrates, microdistribution, microhabitats, dredging.

1. The importance of microhabitat characteristics for macroinvertebrate microdistribution was studied within a reach of the main channel of the Upper Rhône River (France). 9 locations ( 3 on the left hand side, 3 across the middle, and 3 on the right hand side) were sampled twice on two dates (as duplicates in June and July 1982). From 19 variables, including substratum and hydraulic parameters, 14 were selected to describe the physical habitat of each location. 47 macroinvertebrate species were collected by means of dredging with a modified Rallier du Baty dredge. The habitat-fauna co-structure was studied using co-inertia analysis.

2. The river reach was transversally asymmetrical : shallow on one side (up to $2.80 \mathrm{~m}$ ) with coarse sediments rich in periphyton, and much deeper on the other side (up to $4.80 \mathrm{~m}$ ) with a gravel bottom rich in organic particles. In the middle of the channel these conditions were intermediate, but the current was stronger. Velocity and the other hydraulic parameters varied independently of the substratum characteristics. This independence is a consequence of old man-made impoundments (inherited structures) and perhaps of present paving of the substratum also.

3. The macroinvertebrate fauna was closely linked to this transverse asymmetry of the reach, with the highest richness and abundance to the shallow side of the channel and the lowest species richness in the rapid central part. The most significant faunistic differences were linked i) to water depth, acting on both hydraulic parameters and periphyton (by light transmission), ii) to the inherited old bottom substratum, and iii) to a lesser extent, to the present current velocity.

Importance des caractéristiques du microhabitat sur la microdistribution du macrobenthos d'une portion du Haut-Rhône (France)

Mots clés : fleuve, Rhône, macroinvertébrés, microdistribution, microhabitats, dragage.

1. L'importance relative des caractéristiques du microhabitat sur la microdistribution du macrobenthos a été étudiée dans une portion du cours principal du Haut-Rhône (France). 9 points ont été échantillonnés 2 fois à 2 dates (juin et juillet 1982). Sur 19 variables incluant des paramètres granulométriques et hydrauliques, 14 ont été prises en compte pour décrire l'habitat physique en chaque point. 47 espèces de macroinvertébrés ont été collectées par dragage (drague Rallier du Baty modifiée). La co-structure habitat-faune a été étudiée au moyen d'une analyse de co-inertie.

2. La portion de chenal étudiée présentait une asymétrie transversale avec, un côté peu profond (minimum $2,80 \mathrm{~m}$ ) à sédiments grossiers recouverts de périphyton, et un côté plus profond (maximum 4,80 m) à sédiments graveleux riches en débris organiques. Au milieu du chenal, ces conditions étaient intermédiaires mais avec un courant plus élevé. Ainsi la vitesse du courant variait de façon indépendante des caractéristiques du substrat. Cette indépendance est une conséquence d'aménagements antérieurs (structure héritée) et, peut-être aussi, d'un pavage actuel du fond.

3. La faune macrobenthique était étroitement corrélée à l'asymétrie transversale de cette portion du chenal. La richesse et l'abondance faunistique étaient plus élevées du côté peu profond et plus faibles au centre du chenal. Les différences faunistiques les plus significatives étaient liées i) à la profondeur, qui intégrait les paramètres hydrauliques et à l'abondance du périphyton (transmisson de la lumière), ii) au substrat (structure héritée), et iii) de façon moins significative, à la vitesse actuelle du courant.

1. ESA CNRS 5023, Ecologie des eaux douces et des grands fleuves, Univ. Lyon I, F-69622 Villeurbanne Cedex, France. 


\section{Introduction}

Ecological and faunistic changes along the transverse dimension in floodplain river systems are well documented (e.g. Ward 1988, 1989). A recent analysis of habitat use by several groups of organisms in the Upper Rhône River (France) highlighted a faunistic gradient of 22 aquatic habitat types from the main channel towards the most terrestrial habitats (Dolédec \& Statzner 1994). There is, however, less information available on the transversal dimension within the main channel, because of the difficulties of direct investigation in this deep and lotic system, and also because it often seemed a priori rather homogeneous when we considered the water surface.

Some studies have examined the distribution of benthic macroinvertebrates in the main channel of a large river : Russian Rivers (Zhadin \& Gerd 1961), the River Tisza in Hungary (Ferencz 1974 a, b), the River St Lawrence (Vincent \& Vaillancourt 1978), the River Mississippi (Wells \& Demas 1979, Andersen \& Day 1986), the River Rhône (Gaschignard et al. 1983), the River Rhine (Sopp 1983), the River Main (Schleuter \& Tittizer 1988). The most obvious differences have been found between the channel and the riparian systems (banks). However, these studies did not demonstrate the influence of microhabitat characteristics, and particularly hydraulic conditions, on the microdistribution of macrobenthos in the main channel itself.

In the present study, we examine the relative importance of microhabitat characteristics on the macrobenthos across the main channel of a wide, deep lotic reach of the Upper Rhône River. Hydraulic measurements and direct sampling of the river bed using a dredge, made it possible to compare benthic conditions and macroinvertebrate assemblages. This allowed us to take into account historical or present-day physical habitat features and to search, with appropriate new statistical methods, for those which best explain the pattern of the transversal microdistribution of macroinvertebrates.

\section{Material and methods}

\subsection{The reach and sampling}

The studied reach is in the Upper Rhône, $27 \mathrm{~km}$ upstream from Lyon, France (Fig. 1A). It is located downstream of the confluence with the Ain River, and is influenced by the regulating dam of Jons (Fig. 1B) which reduces the water level variations to less than $50 \mathrm{~cm}$. Mean annual discharge is $630 \mathrm{~m}^{3} \cdot \mathrm{s}^{-1}$ over the period 1920-1990 (data from the Compagnie Nationale du Rhône). The steep banks are protected by boulder embankments that were built around 1885 (Fig. 1C). The embankments are covered with riparian vegetation, particularly Salix and Alnus. The reach is $150 \mathrm{~m}$ wide and $140 \mathrm{~m}$ long with a maximum depth of $5 \mathrm{~m}$. Sampling was carried out at 9 locations, three along the right bank, three across the middle of the channel and three along the left bank (Fig. 1D). These locations were sampled twice, as duplicates side by side at two dates : June 17th and July 22th in 1982 (total of 36 samples). Summer was chosen because it corresponds to a period of high richness and relative stability of the benthic fauna in the Upper Rhône River (Perrin \& Roux 1978, Berly 1989, Tachet et al. 1991). Nevertheless there were some changes in environmental parameters between the two dates : for instance, in June and July respectively, the water temperature was $15^{\circ} \mathrm{C}$ and $22.5^{\circ} \mathrm{C}$, and the mean daily discharge was 796 and $623 \mathrm{~m}^{3} \cdot \mathrm{s}^{-1}$.

From a boat, 36 measurements of the current velocity one meter above the bottom $\left(\mathrm{V}_{1 \mathrm{~m}}\right)$ and water depth (D) were taken using a Dumas Neyrpic propeller flowmeter. At the same time, 36 macroinvertebrate and sediment samples were collected using a modified Rallier du Baty-style dredge (Boillot 1964). The opening diameter of the dredge is $30 \mathrm{~cm}$ for a total weight of $25 \mathrm{~kg}$. An external plastic bag protected a fine net ( $0.5 \mathrm{~mm}$ mesh size), which retained both the substrate materials and organisms (Fig. 2A, B). The median heavy axis and chain enabled the dredge to enter the sediment layer at the correct angle (Fig. 2C). Tests in shallow water have shown that this dredge sampled a sediment layer of almost $10 \mathrm{~cm}$. From the boat it was impossible to know the exact length of river bottom across which the dredge was pulled. Moreover, the maximum quantity of sampled sediment is limited to about 10 litres by the inner volume of the net. Thus, all quantities were evaluated per volume of sampled sediment. Each whole sample was washed into a basin; all the stones except the tiny ones were brushed and the washing water was kept cold for chlorophyll evaluations. The remaining sediment, organic material and associated macroinvertebrates were stored in $10 \%$ formalin.

\subsection{Habitat variables}

\subsubsection{Sediment measurements}

After the macroinvertebrates had been hand sorted, each sample was washed through different sieves in order to separate the different sizes of organic and mineral particles.

Particulate organic material was carefully separated by swirling and sieving into four classes : fine particu- 


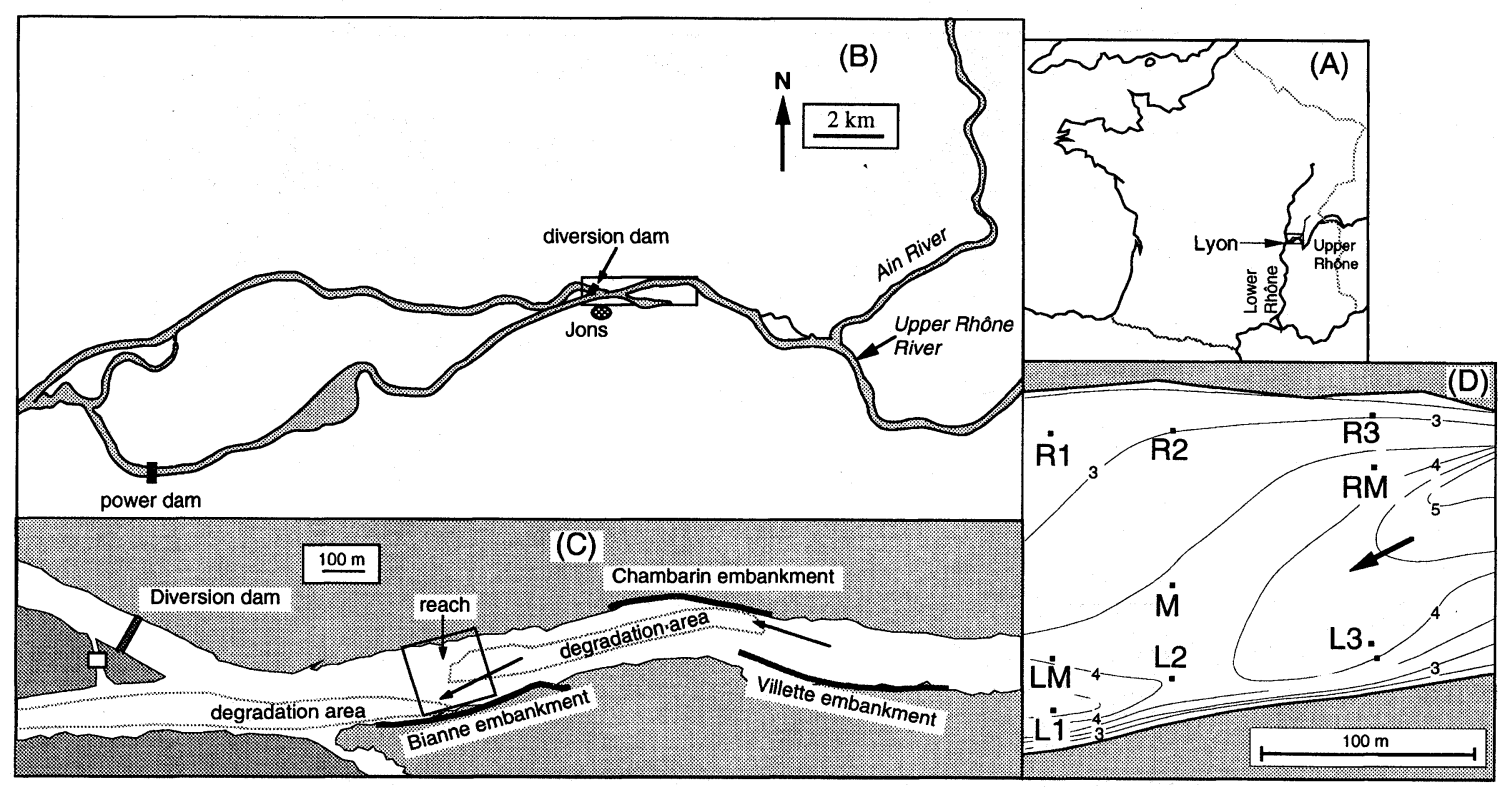

Fig. 1. (A) Situation of the Rhône River in France. (B) The area on the last kilometers of the Upper Rhône. (C) The Jons area; this map is adapted from a map drawn between 1857 and 1866 by the Administration des Ponts et Chaussées (Anonymous, 1857-1866); in this braided section, three embankments were built which have modified sedimentation and current direction. (D) The reach with the nine sampling locations and the isodepth curves. R1, R2 and R3 sampling locations at about 5 meters from the right hand bank; L1, L2 and L3 idem for the left hand bank; RM, M and RM sampling locations at about $20 \mathrm{~m}$ from the right hand bank, in the middle of the channel and at about $20 \mathrm{~m}$ from the left hand bank, respectively.

Fig. 1. (A) Le Rhône en France. (B) Les derniers kilomètres du Haut-Rhône. (C) Le secteur de Jons; cette carte est adaptée d'une carte dressée entre 1857 et 1866 par l'Administration des Ponts et Chaussées (Anonyme, 1857-1866); dans ce secteur de tressage, la construction de trois endiguements a eu pour effet de modifier la sédimentation et la direction du courant. (D) La portion de chenal étudiée avec les 9 points d'échantillonnage et les courbes isobathes. Les points R1, R2 et R3 et les points L1, L2 et L3 sont situés à environ $5 \mathrm{~m}$ respectivement de la rive droite et de la rive gauche, les points RM et LM sont situés à environ $20 \mathrm{~m}$ des rives droite et gauche et le point $\mathrm{M}$ au milieu du chenal.

late organic matter (FPOM $<1 \mathrm{~mm})$, medium particulate organic matter $(1<\mathrm{MPOM}<4 \mathrm{~mm})$ and coarser particles $(>4 \mathrm{~mm})$ that were further visually separated into wood particles (WOO) and other coarse organic matter (CPOM, mainly leaves). Particles were dried at $60^{\circ} \mathrm{C}$ for $48 \mathrm{~h}$, and ash free dry weight (AFDW) was determined after ashing at $550^{\circ} \mathrm{C}$.

The mineral sediments that remained after collecting the POM were separated by sieving according to Wentworth's classification (Tolkamp 1982). Eight classes were determined : cobbles $(64-128 \mathrm{~mm})$; large (32$64 \mathrm{~mm})$ and small $(16-32 \mathrm{~mm})$ pebbles; coarse $(8-$ $16 \mathrm{~mm})$, medium $(4-8 \mathrm{~mm})$ and fine $(2-4 \mathrm{~mm})$ gravel; coarse sand (1-2 $\mathrm{mm})$ and finer sand particles $(<$ $1 \mathrm{~mm}$ ). This distribution of grain size enabled the substratum roughness $\left(\mathrm{k}_{\mathrm{v}}\right)$ to be evaluated using Winget's method (1985), i.e. $\mathrm{k}_{\mathrm{v}}=\left(5 \mathrm{C}_{1}+3 \mathrm{C}_{2}+\mathrm{C}_{3}\right) / 9$, where $\mathrm{C}_{1}$, $\mathrm{C}_{2}$ and $\mathrm{C}_{3}$ are the coarseness values of the most dominant, second most dominant and third most dominant substrate types respectively. Coarseness values for C refer to substratum size classes. This index $\mathrm{k}_{\mathrm{v}}$ (in $\mathrm{cm}$ ) is an evaluation of the protrusion of the bottom into the water (Statzner et al. 1988).

From the washing water, the quantity of epilithic algae was evaluated by chlorophyll a content (Chl). Algal suspension in 100 to $200 \mathrm{~cm}^{3}$ of prefiltered $(0.5 \mathrm{~mm})$ washing water was retained on a Whatman GF/C $4.7 \mathrm{~mm}$ filter by vacuum filtration, according to Lorenzen's method (1967). Chlorophyll a was estimated spectrophotometrically after extraction in acetone, according to the equations of Strickland \& Parsons (1972).

\subsubsection{Hydraulic parameters}

The mean velocity in the water column $\left(\mathrm{V}_{\mathrm{m}}\right)$ was inferred from the velocity measured one meter above the bottom $\left(\mathrm{V}_{1 \mathrm{~m}}\right)$. We used the very good relationship, $\mathrm{V}_{\mathrm{m}}$ $=0.974 \mathrm{~V}_{1 \mathrm{~m}}+1.273(\mathrm{r}=0.979$ for $\mathrm{n}=84)$, from current 

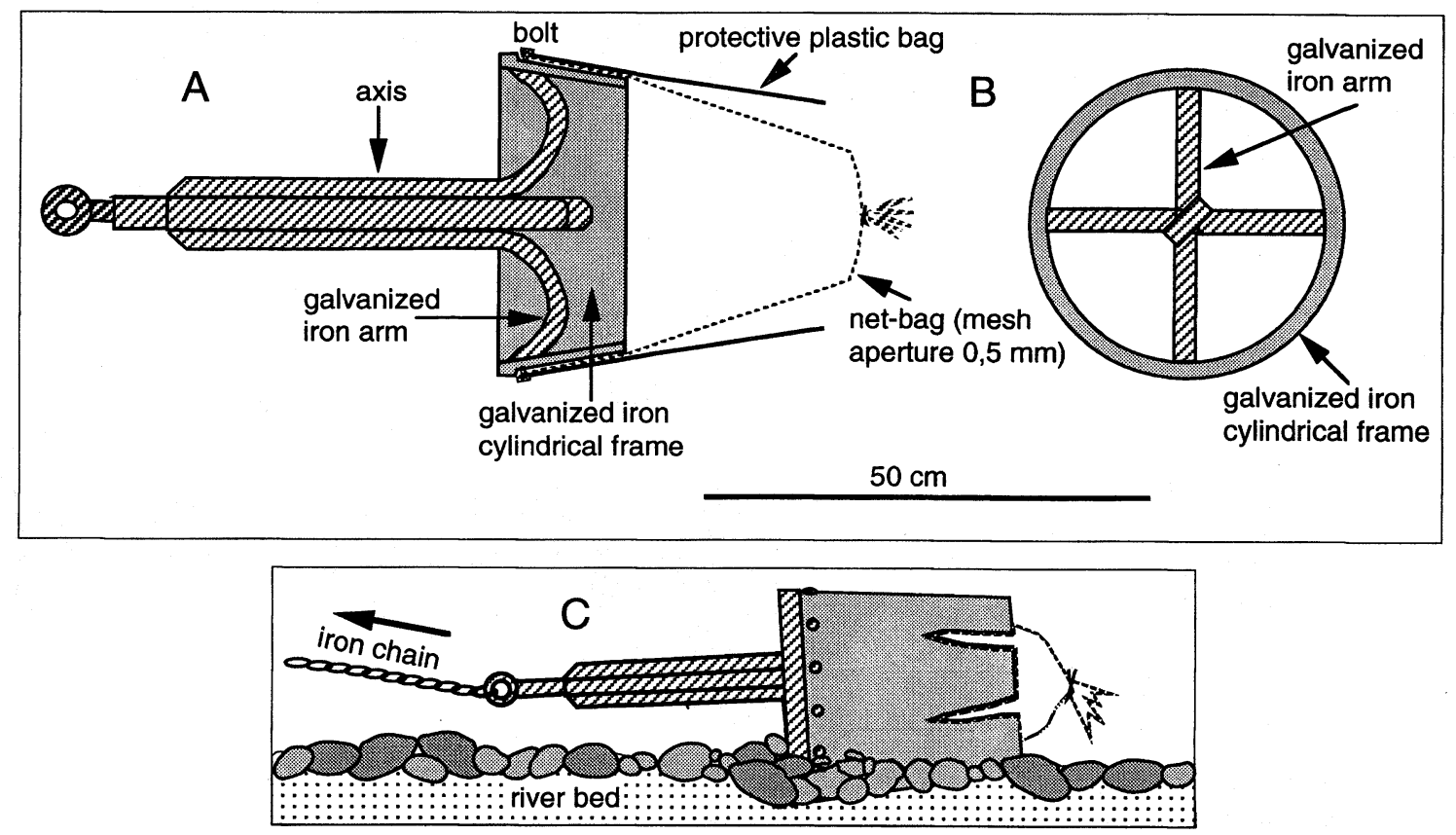

Fig. 2. The Rallier du Baty dredge. (A) Longitudinal section through the dredge; a series of bolts screwed on to the cylindrical frame holds the net-bag and the protective plastic-bag. (B) Front view of the opening. (C) Side view of the dredge in operation on the river bed.

Fig. 2. La drague Rallier du Baty. (A) Section longitudinale de la drague; une série de boulons permet d'attacher le filet et le plastique protecteur au cadre cylindrique. (B) Vue frontale de l'ouverture. (C) Vue latérale de la drague en action sur le fond.

velocity profiles taken in a previous study in the same reach with discharges from 150 to $1150 \mathrm{~m}^{3} \cdot \mathrm{s}^{-1}$ (Cellot \& Bournaud 1984).

The mean velocity $\left(\mathrm{V}_{\mathrm{m}}\right)$ and the depth (D) of water column made it possible to calculate several parameters that take into account the hydraulic effects of current (Statzner et al. 1988). The first is the Reynolds number, $R e=V_{m} \cdot D \cdot v^{-1}$ (where $v=$ kinematic water viscosity, see Smith (1975) for details on the calculation); it provides an indication of free flow turbulence. The second parameter is the Froude number, $\mathrm{Fr}=$ $\mathrm{V}_{\mathrm{m}} \cdot \mathrm{D}^{-0.5} \cdot \mathrm{g}^{-0.5}$ (where $\mathrm{g}=$ acceleration due to gravity); it evaluates the streaming or shooting flow, and can be used as an indication of the force acting per area on the bottom, as well as of the roughness of the water surface which is generally responsible for the decrease in light that reaches the bottom (Statzner et al. 1988). The third parameter is the shear velocity, $\mathrm{U}^{*}=\mathrm{V}_{\mathrm{m}} / 5.75$ $\log \left(12 \mathrm{D} / \mathrm{k}_{\mathrm{v}}\right)$; this enables the bottom shear stress to be evaluated, using $U^{* 2}$ (Statzner et al. 1991). The fourth parameter is the boundary Reynolds number,
$\mathrm{bRe}=\mathrm{U}^{*} \mathrm{k}_{\mathrm{v}} / \mathrm{v}$, which provides an indication of the turbulence close to the bottom (Statzner et al. 1988, Quinn and Hickey 1994).

\subsection{Data analysis}

\subsubsection{Redundant habitat variables}

Habitat description yielded 19 variables : four for organic sediments (FPOM, MPOM, WOO and CPOM); nine for mineral sediments (eight for grain size classes from cobbles to fine sand and $\mathrm{k}_{\mathrm{v}}$ ) and six hydraulic parameters $\left(\mathrm{V}_{\mathrm{m}}, \mathrm{D}, \mathrm{Re}, \mathrm{Fr}, \mathrm{U}^{* 2}\right.$ and $\left.\mathrm{bRe}\right)$. In order to reduce this number, we examined possible redundancy in these variables, especially for the grain size classes of mineral sediment and for the hydraulic parameters.

The weights of the eight classes of mineral sediment were transformed into percentages of total weight for each of the 36 samples. A Principal Component Analysis (PCA) was carried out on the table centered by size class (Gaschignard \& El Hamdi 1984). The samples were thus at the conditional mean of the scores of the grain size classes in the biplot distance representation 
Table 1. Principal Component Analysis on 8 sediment size classes in 36 samples in the Rhône River reach : scores of the size classes on the F1, F2 and F3 axes, with explained inertia in \%.

Tableau 1. Pourcentage d'inertie d'une Analyse en Composantes Principales sur 8 classes granulométriques pour 36 échantillons provenant de la portion de Rhône étudiée : pourcentage d'inertie expliquée pour F1, F2 et F3, et pour chaque classe granulométrique, coordonnées sur F1, F2 et F3.

\begin{tabular}{lccccc}
\hline measured grain size classes $(\mathrm{mm})$ & $\begin{array}{c}\mathrm{F} 1 \\
(52,5 \%)\end{array}$ & $\begin{array}{c}\mathrm{F} 2 \\
(33,3 \%)\end{array}$ & $\begin{array}{c}\mathrm{F} 3 \\
(11,0 \%)\end{array}$ & $\begin{array}{l}\text { Retained } \\
\text { classes }\end{array}$ & Code \\
\hline \hline Cobbles (64-128) & -0.036 & $\mathbf{0 . 0 6 2}$ & $\mathbf{0 . 0 8 5}$ & Cobbles & Cob \\
\hline Large pebbles (32-64) & -0.096 & $\mathbf{0 . 1 1 9}$ & -0.051 & Pebbles & Peb \\
\hline Small pebbles (16-32) & -0.06 & 0.061 & -0.032 & & \\
Coarse gravels (8-16) & -0.012 & 0.088 & -0.004 & & \\
Medium gravels (4-8) & -0.003 & 0.055 & 0.01 & "Gravels" & Gr \\
Fine gravels (2-4) & 0.004 & 0.016 & 0.008 & & \\
Coarse sand (1-2) & 0.001 & 0.005 & 0.002 & & \\
\hline Fine sand $(<1)$ & $\mathbf{0 . 2 0 1}$ & 0.044 & -0.019 & Sand & San \\
\hline
\end{tabular}

of Gabriel (1971) and Ter Braak (1983). This is a generalization of the triangular representation (Gower 1967). The procedure shows, on the first three main PCA axes, how the grain size classes could be grouped together (Table 1). The F1 axis separated the fine sand ( $<1 \mathrm{~mm}$ ) from all other groups. The F2 axis separated the large pebbles and cobbles (>32 $\mathrm{mm}$ ), whereas the F3 axis highlighted differences between cobbles and large pebbles. The other classes, from small pebbles to coarse sand, were not distinguished because they had the same distribution among the 36 samples and could be grouped together. The three axes, which explained $96.8 \%$ of the inertia in the PCA analysis, therefore made it possible to retain only four classes of grain size of mineral sediment variables : Cobbles (Cob, 64$128 \mathrm{~mm}$ ), Pebbles (Peb, 32-64 mm), «Gravel» (Gr, 1$32 \mathrm{~mm}$ ) and Sand (San, < $1 \mathrm{~mm}$ ).

The correlations between the six hydraulic parameters, four of which ( $\mathrm{Re}, \mathrm{Fr}, \mathrm{U}^{* 2}$ and $\mathrm{bRe}$ ) were computed mainly using the measurements of $D$ and $V_{m}$, were also calculated in order to determine which were redundant. Correlation coefficients between three of them, the water velocity $\left(\mathrm{V}_{\mathrm{m}}\right.$, the Froude number $(\mathrm{Fr})$ and the shear stress $\left(U^{* 2}\right)$, exceeded 0.96 . We therefore retained only $\mathrm{V}_{\mathrm{m}}$. The two Reynolds numbers $\operatorname{Re}$ and bRe had lower correlations between each other and with the preceding variables (from 0.75 to 0.87 ). They were both retained, as were $V_{m}$ and $D$, which represent the hydraulic conditions at the sampling locations.

Finally, 14 variables were taken into account in the habitat matrix $\mathrm{H}$ (Table 2). They included particulate organic matter (4 variables), mineral sediments (grain size classes : 4 , and bottom roughness : 1 ), chlorophyll a (1) and hydraulic parameters (4).

\subsubsection{Separation of sampling effects}

The habitat matrix $\mathrm{H}$ was normalized as is usual for variables with different units (Carrel et al. 1986). The faunistic matrix $F$, expressed as the number of individuals per 10 litres of sediments given in Table 3, was $\log _{10}$ transformed to reduce variances and was centered in order to take into account quantitative aspects of the spatial distribution of the macroinvertebrates (Dolédec \& Chessel 1991). The inertia of Principal Component Analyses (PCA) of these matrices provided a measurement of the total variability of these data tables.

The sampling design dealt with three possible effects : the location effect in the reach (nine classes), the duplicate for each location at a given date (two classes) and the sampling date (two classes). Each of these effects has been taken into account by between-classes PCA, which analyzed the data cumulated by classes (Dolédec \& Chessel 1989, 1991). The inertia of these analyzes was a measure of the part of the total inertia that was linked to the class effect, i.e. the betweenclasses variability. Therefore, this procedure made it possible to decompose the total inertia of the matrices $\mathrm{H}$ and $\mathrm{F}$ and introduced, at the multivariate level, the principles of an analysis of variance (Lebreton et al. 1991). Using this partition of the total inertia, the relative importance of sampling effects (two dates and two duplicates) could be compared and the pertinence of the location effect could be tested. 
Table 2. Habitat variables (mean of two measurements) at sampling locations. FPOM, MPOM, CPOM = respectively Fine $(<1 \mathrm{~mm})$, Medium (1-4 mm), Coarse (> $4 \mathrm{~mm}$ ) Particulate Organic Material; Woo=woody detritus (all expressed in $\mathrm{mg}$ AFDW $/ 1$ of sediment); Cob = cobbles $(>64 \mathrm{~mm}) ; \mathrm{Peb}=$ pebbles $(32-64 \mathrm{~mm}) ; \mathrm{Gr}=$ «gravels» $(1-32 \mathrm{~mm}) ; \mathrm{San}=$ sand $(<1 \mathrm{~mm}) ; \mathrm{K}_{\mathrm{v}}=$ bottom roughness; $\mathrm{Chl}=$ chlorophyll $\mathrm{a} ; \mathrm{D}=$ water depth; $\mathrm{V}_{\mathrm{m}}=$ mean current velocity $; \mathrm{Re}=$ Reynolds number; bRe = boundary Reynolds number. For Re the values are multiplied by $10^{-6}$ and for bRe by $10^{-3}$.

Tableau 2. Variables d'habitat (moyenne de deux mesures) au niveau des points d'échantillonnage. FPOM, MPOM, CPOM = respectivement particules organiques fines $(<1 \mathrm{~mm})$, moyennes $(1-4 \mathrm{~mm})$ et grossières $(>4 \mathrm{~mm})$; Woo = débris ligneux (valeurs exprimées en mg. $1^{-1}$ de sédiment); Cob = pierres (> $\left.64 \mathrm{~mm}\right) ; \mathrm{Peb}=$ cailloux $(32-64 \mathrm{~mm}) ; \mathrm{Gr}=$ «graviers» $(1-32 \mathrm{~mm})$; San = sables $(1 \mathrm{~mm}) ; \mathrm{K}_{\mathrm{v}}=$ rugosité du fond; $\mathrm{Chl}=$ Chlorophylle $\mathrm{a} ; \mathrm{D}=$ profondeur; $\mathrm{V}_{\mathrm{m}}=$ vitesse moyenne du courant; $\mathrm{Re}=$ nombre de $\mathrm{Rey}-$ nold; $b R e=$ Nombre de Reynold pour la couche limite. Pour Re, les valeurs sont multipliées par 10-6 et pour bRe par $10^{-3}$.

\begin{tabular}{|c|c|c|c|c|c|c|c|c|c|c|c|c|c|c|c|c|c|c|}
\hline \multirow{3}{*}{$\begin{array}{c}\text { Habitat } \\
\text { Variables }\end{array}$} & \multicolumn{18}{|c|}{ Sampling points } \\
\hline & \multicolumn{9}{|c|}{ June } & \multicolumn{9}{|c|}{ July } \\
\hline & L1 & L2 & L3 & LM & M & $\mathbf{R M}$ & R1 & R2 & R3 & L1 & L2 & L3 & LM & $M$ & $\mathbf{R M}$ & R1 & R2 & R3 \\
\hline FPOM & 5.6 & 5.8 & 5.8 & 3.9 & 4.8 & 3.1 & 8.8 & 4.2 & 4.1 & 5.7 & 6.6 & 6.2 & 7.8 & 5.5 & 2.6 & 4.4 & 4.0 & 4.4 \\
\hline MPOM & 5.1 & 5.4 & 4.7 & 5.1 & 5.3 & 2.9 & 2.9 & 4.3 & 3.8 & 5.6 & 5.6 & 4.9 & 7.1 & 5.4 & 2.4 & 4.7 & 4.1 & 2.9 \\
\hline СРОМ & 3.0 & 1.6 & 3.1 & 3.0 & 4.1 & 2.7 & 1.8 & 2.1 & 3.0 & 4.0 & 3.0 & 3.1 & 5.7 & 4.1 & 2.3 & 4.1 & 1.4 & 0.4 \\
\hline Woo & 3.5 & 5.4 & 5.2 & 5.6 & 4.9 & 0.0 & 2.4 & 3.4 & 1.7 & 2.4 & 3.0 & 3.4 & 7.1 & 4.7 & 2.4 & 4.8 & 3.5 & 0.9 \\
\hline $\operatorname{Cob}(\%)$ & 6.7 & 32.2 & 7.5 & 0.0 & 4.0 & 21.5 & 4.0 & 11.2 & 6.6 & 1.1 & 1.5 & 5.8 & 0.0 & 15.7 & 24.9 & 5.1 & 3.4 & 14.5 \\
\hline Peb (\%) & 16.6 & 22.8 & 23.8 & 20.9 & 31.8 & 35.3 & 31.7 & 38.8 & 39.0 & 15.2 & 6.3 & 16.0 & 10.8 & 32.3 & 52.7 & 43.5 & 54.6 & 42.7 \\
\hline $\operatorname{Gr}(\%)$ & 76.0 & 42.6 & 18.5 & 78.9 & 60.9 & 43.3 & 15.3 & 50.0 & 54.4 & 81.7 & 83.9 & 73.1 & 63.4 & 46.7 & 22.4 & 51.3 & 42.0 & 34.1 \\
\hline ) & 0.8 & 2.5 & 50.3 & 0.2 & 3.3 & 0.0 & 49.1 & 0.0 & 0.1 & 2.0 & 8.3 & 5.2 & 25.9 & 5.5 & 0.0 & 0.1 & 0.1 & 8.8 \\
\hline $\mathrm{Kv}(\mathrm{cm})$ & 3.2 & 3.3 & 2.0 & 3.2 & 3.2 & 3.2 & 2.6 & 3.4 & 3.2 & 3.2 & 2.6 & 3.2 & 2.6 & 3.3 & 3.44 & 3.33 & 3.44 & 3.385 \\
\hline Chl (mg/l) & 3.0 & 3.1 & 3.5 & 2.8 & 3.3 & 4.6 & 6.4 & 4.7 & 5.1 & 3.3 & 3.3 & 3.6 & 3.0 & 3.5 & 3.6 & 4.3 & 4.2 & 4.2 \\
\hline$D(\mathrm{~cm})$ & 480 & 410 & 420 & 410 & 380 & 380 & 280 & 330 & 340 & 480 & 410 & 460 & 400 & 400 & 360 & 280 & 300 & 360 \\
\hline $\mathrm{Vm}(\mathrm{cm} / \mathrm{s})$ & 79 & 52 & 59 & 111 & 123 & 141 & 81 & 101 & 78 & 78 & 65 & 40 & 94 & 88 & 104 & 43 & 76 & 58 \\
\hline $\operatorname{Re}$ & 3.31 & 1.86 & 2.16 & 3.98 & 4.08 & 4.68 & 1.98 & 2.91 & 2.32 & 3.93 & 2.8 & 1.93 & 3.95 & 3.7 & 3.93 & 1.26 & 2.39 & 2.19 \\
\hline $\mathrm{bRe}$ & 1.19 & 0.83 & 0.55 & 1.71 & 1.91 & 2.19 & 1.01 & 1.73 & 1.23 & 1.38 & 0.95 & 0.73 & 1.35 & 1.67 & 2.11 & 0.87 & 1.58 & 1.16 \\
\hline
\end{tabular}

\subsubsection{Habitat and fauna co-variation}

The co-structure of the two matrices, $\mathrm{H}$ and $\mathrm{F}$, which referred to the same sampling locations, was studied by a co-inertia analysis (Chessel $\&$ Mercier 1993). The co-inertia analysis maximized the correlation between the two structures : the habitat structure and the fauna structure (Dolédec \& Chessel 1994). The optimizing criterion was that the resulting sample scores, the habitat scores for matrix $\mathrm{H}$ and the faunistic scores for matrix F, were the most covariant and could be compared directly on the same factorial map. The factorial maps of habitat variables and species enabled the habitat and fauna characteristics of the reach to be explained simultaneously. Thus, the habitat and fauna scores of the nine sampling locations were projected upon a reach map, as a synthetic representation of the spatial distribution of the variables.

All computations and graphics were carried out using the ADE Software, a package for Multivariate Analysis and Graphical Display for Environmental Data (version 3.6) (Chessel \& Dolédec 1993).

\section{Results}

\subsection{Variability observed in the habitat and faunis- tic data}

The variability of habitat (matrix $\mathrm{H}=14$ variables $\mathrm{x} 36$ samples) and faunistic (matrix $F=47$ species $\times 36$ samples) data was examined by means of analyses of inertia.

The decomposition of the total inertia for each data table $\mathrm{H}$ and $\mathrm{F}$ is presented in Table 4. Firstly, the sum of the inertia of the three effects in the sampling design accounted for a large part of the variability : 60.7 and $65.6 \%$ for habitat and fauna, respectively. Secondly, the spatial variability (location effect) was high, with $56.8 \%$ (habitat) and $42.6 \%$ (fauna) of the total inertia. The duplicate effect accounted for less than $2 \%$ of inertia in each table. The differences between June and July were also very small ( $2.1 \%$ of the total inertia) for habitat measures, whereas faunistic differences were substantial in this case (21.4\% of the total inertia).

A detailed examination of the analysis of inertia showed that variations between the two dates dealt espe- 
Table 3a. Abundance (mean of two samples) of 47 species (number of animals per 10 litres of dredged sediment) for June 1982 at 9 locations of the Rhône River reach. For Coleoptera and Empidida e: 1 = larva; $p=$ pupa; $i=$ imago.

Tableau 3a. Abondance (moyenne de deux échantillons) des 47 espèces (nombre d'animaux pour 10 litres de sédiments dragués) en juin 1982 dans les 9 points de la portion étudiée. Pour les Coléoptères et les Empididae : $1=$ larve ; $p=$ nymphe ; $i=i m a g o$.

\begin{tabular}{|c|c|c|c|c|c|c|c|c|c|}
\hline \multirow[b]{2}{*}{ Species } & \multicolumn{9}{|c|}{ Sampling points } \\
\hline & L1 & L2 & L3 & LM & $\mathbf{M}$ & $\mathbf{R M}$ & R1 & $\mathbf{R 2}$ & R3 \\
\hline Hydra sp. & 170.2 & 432.9 & 107.7 & 305.7 & 350.7 & 60.9 & 1541.3 & 209.4 & 1235.0 \\
\hline Dugesia tigrina (Girard) & - & 10.0 & 1.8 & - & 1.0 & - & 6.7 & 8.2 & 26.3 \\
\hline Dendrocoelum lacteum (O.F. Müller) & - & 0.7 & 3.6 & - & - & - & 12.5 & 5.1 & 16.6 \\
\hline Polycelis nigra-tenuis & - & 2.1 & 1.8 & - & - & - & 4.6 & 1.6 & 6.3 \\
\hline Helobdella stagnalis (L.) & 7.9 & 10.9 & 2.0 & 2.8 & 1.0 & - & 13.8 & 31.3 & 65.7 \\
\hline Erpobdella octoculata (L.) & 1.5 & 0.7 & - & 1.0 & $\cdot$ & - & 7.9 & 5.7 & 9.2 \\
\hline Theodoxus fluviatilis $L$. & - & - & - & - & - & - & - & - & 1.0 \\
\hline Valvata cristata O.F. Müller & - & - & - & - & - & - & - & - & 5.6 \\
\hline Bithynia tentaculata $L$. & - & - & - & - & - & - & 2.5 & 3.8 & 7.2 \\
\hline Potamopyrgus antipodarum (Gray) & 1.5 & - & 1.8 & - & - & - & - & - & 2.2 \\
\hline Ancylus fluviatilis O.F. Müller & - & 3.4 & - & - & - & - & - & 1.9 & - \\
\hline Dreissena polymorpha Pallas & - & - & - & - & - & - & - & 0.7 & 4.9 \\
\hline Sphaerium corneum $L$. & - & - & - & - & - & - & 1.3 & 2.2 & 11.3 \\
\hline Pisidium casertanum Poli & - & - & - & - & - & - & - & 1.6 & 1.5 \\
\hline Pisidium subtruncatum Malm & - & - & - & - & - & - & - & 0.3 & 0.7 \\
\hline Gammarus fossarum-pulex & 1114.3 & 2045.9 & 1097.2 & 216.1 & 205.6 & 39.2 & 1872.9 & 1267.5 & 1737.9 \\
\hline Asellus aquaticus $L$. & - & 0.7 & - & - & - & - & - & 0.7 & - \\
\hline Baetis sp. (gr. fuscatus) & 2.2 & 1.3 & 1.8 & 0.9 & 10.2 & 9.1 & 65.4 & 16.3 & 28.5 \\
\hline Heptagenia sulphurea Müller & 0.7 & 18.4 & 2.0 & 0.9 & - & 13.9 & 77.1 & 33.2 & 39.3 \\
\hline Heptagenia caerulans Rost & - & 2.1 & 1.8 & - & - & - & - & 1.0 & 0.7 \\
\hline Rhithrogena sp. (gr. semicolorata) & 2.2 & - & - & 1.7 & 5.6 & 5.9 & 10.0 & 1.0 & 1.0 \\
\hline Ephemerella ignita Poda & 0.7 & - & 3.8 & 1.0 & 4.6 & 0.9 & 37.1 & 6.0 & 4.2 \\
\hline Ephemera danica Müller & - & - & - & - & - & - & 1.3 & - & - \\
\hline Caenis luctuosa (Burmeister) & - & - & - & - & - & - & 2.5 & 1.3 & 2.2 \\
\hline Chloroperla tripunctata Scop & - & - & - & - & - & - & - & - & - \\
\hline Leuctra sp. (gr. fusca) & 6.7 & - & 1.8 & - & - & - & 3.4 & - & - \\
\hline Euleuctra geniculata Steph & - & - & - & - & - & - & - & 1.3 & - \\
\hline Sysira fuscata Fbr & - & - & - & 0.9 & - & - & - & - & - \\
\hline Orectochilus villosus Müller & - & - & - & - & - & - & - & - & - \\
\hline Elmis aenea (Ph. Müller) (I) & - & - & - & - & - & - & 13.4 & 0.7 & - \\
\hline Esolus parallelepipedus (Ph. Müller) $(l+i)$ & 1.1 & 0.7 & - & - & - & 1.0 & 12.5 & 11.0 & 8.5 \\
\hline Limnius volckmari Panzer (I) & - & - & 2.8 & - & - & - & - & 1.6 & 0.7 \\
\hline Psychomyia pusilla (Fabr.) & - & 5.9 & - & 2.9 & 9.2 & 2.6 & 31.3 & 1.3 & 1.0 \\
\hline Hydropsyche modesta Navas & 2.9 & 24.8 & 7.6 & 1.8 & - & 0.9 & 17.9 & 53.5 & 20.2 \\
\hline Hydropsyche contubernalis McL & 6.8 & 30.0 & 10.2 & 1.0 & - & 2.5 & 30.4 & 40.1 & 56.3 \\
\hline Hydropsyche exocellata Dufour & 0.7 & 2.8 & 3.6 & - & - & 0.9 & 1.3 & 3.2 & 3.5 \\
\hline Hydropsyche siltalaï Döhler & - & - & - & - & - & 0.9 & - & 1.3 & 1.5 \\
\hline Hydropsyche ornatula McL & - & 1.3 & 1.0 & - & - & - & - & 1.9 & 0.7 \\
\hline Hydropsyche pellucidula (Curt.) & - & - & - & - & - & - & - & - & . \\
\hline Cheumatopsyche lepida (Pict.) & - & - & - & - & - & - & - & 0.7 & 0.7 \\
\hline Athripsodes albifrons $L$. & - & 1.3 & - & - & - & 0.9 & - & 10.7 & 5.0 \\
\hline Ceraclea dissimilis (Steph.) & 2.6 & 4.8 & - & - & - & 2.8 & 20.0 & 12.2 & 30.3 \\
\hline Setodes punctatus Fabr. & 0.7 & 0.7 & 7.2 & - & 1.0 & - & - & - & - \\
\hline Hexatoma sp. & - & - & - & 1.0 & - & - & - & 2.8 & 0.7 \\
\hline Psychoda sp. & - & - & - & 1.8 & - & - & - & - & - \\
\hline Robackia sp. & 5.5 & 1.3 & - & 2.6 & 10.7 & - & 7.9 & - & 0.7 \\
\hline Hemerodromia sp. $(1+p)$ & 15.5 & 15.3 & 3.6 & - & 1.0 & - & - & 2.5 & 5.7 \\
\hline Total & 1343.4 & 2617.2 & 1262.8 & 541.7 & 600.4 & 142.0 & 3794.6 & 1742.5 & 3342.1 \\
\hline
\end{tabular}


Table 3b. Abundance (mean of two samples) of 47 species (number of animals per 10 liters of dredged sediment) for July 1982 at 9 locations of the Rhône River reach. For Coleoptera and Empididae : $1=$ larva; $p=$ pupa; $i=$ imago.

Tableau 3b. Abondance (moyenne de deux échantillons) des 47 espèces (nombre d'animaux pour 10 litres de sédiments dragués) en juillet 1982 dans les 9 points de la portion étudiée. Pour les Coléoptères et les Empididae $: 1=$ larve ; $p=$ nymphe $; i=i m a g o$.

\begin{tabular}{|c|c|c|c|c|c|c|c|c|c|}
\hline \multirow[b]{2}{*}{ Species } & \multicolumn{9}{|c|}{ Sampling points } \\
\hline & $\mathbf{L 1}$ & L2 & L3 & LM & $\mathbf{M}$ & $\mathbf{R M}$ & R1 & $\mathbf{R 2}$ & $\mathbf{R 3}$ \\
\hline Hydra sp. & 2.2 & $\cdot$ & 1.0 & $\cdot$ & 1.1 & 3.5 & 0.8 & - & 2.9 \\
\hline Dugesia tigrina (Girard) & 0.6 & 3.9 & 6.4 & 5.0 & 2.2 & 5.7 & 17.3 & 28.7 & 38.2 \\
\hline Dendrocoelum lacteum (O.F. Müller) & 0.6 & 0.7 & 0.8 & - & - & 0.5 & 5.9 & 12.9 & 4.4 \\
\hline Polycelis nigra-tenuis & - & - & - & - & 1.2 & 1.5 & 2.1 & 5.6 & 1.6 \\
\hline Helobdella stagnalis (L.) & 7.9 & 1.1 & 2.2 & - & $\cdot$ & 3.8 & 35.1 & 37.5 & 76.5 \\
\hline Erpobdella octoculata (L.) & 1.1 & 1.5 & - & - & 2.1 & 10.4 & 10.3 & 7.7 & 22.4 \\
\hline Theodoxus fluviatilis $L$. & $\cdot$ & - & - & 0.9 & 1.1 & - & 0.8 & 0.9 & 3.1 \\
\hline Valvata cristata O.F. Müller & 0.5 & - & - & - & - & - & - & 2.6 & - \\
\hline Bithynia tentaculata $L$. & - & - & - & - & - & 1.5 & 9.0 & 6.6 & 15.1 \\
\hline Potamopyrgus antipodarum (Gray) & - & 1.1 & - & - & - & - & - & - & - \\
\hline Ancylus fluviatilis O.F. Müller & - & 1.1 & 0.5 & 0.9 & - & 1.1 & 1.3 & 1.6 & 2.2 \\
\hline Dreissena polymorpha Pallas & - & $\cdot$ & $\cdot$ & - & - & - & - & - & - \\
\hline Sphaerium corneum $L$. & - & - & - & 5.0 & - & - & 4.4 & 5.9 & 8.3 \\
\hline Pisidium casertanum Poli & $\cdot$ & $\cdot$ & - & - & - & $\cdot$ & - & 0.6 & 0.8 \\
\hline Pisidium subtruncatum Malm & - & - & - & - & 1.1 & - & - & 0.6 & 1.6 \\
\hline Gammarus fossarum-pulex & 489.0 & 2752.4 & 1741,0 & 1575.9 & 472.9 & 603.4 & 1845.5 & 1492.1 & 908.2 \\
\hline Asellus aquaticus $L$. & - & 1.1 & - & - & - & - & - & 0.6 & 1.6 \\
\hline Baetis sp. (gr. fuscatus) & - & 7.0 & 3.2 & 10.0 & 13.7 & 9.2 & 14.9 & 15.4 & 28.6 \\
\hline Heptagenia sulphurea Müller & 1.6 & 60.0 & 42.1 & 10.0 & 41.3 & 70.8 & 119.9 & 104.3 & 146.6 \\
\hline Heptagenia caerulans Rost & - & 1.1 & - & - & 1.7 & 2.1 & 1.6 & 4.5 & 0.8 \\
\hline Rhithrogena sp. (gr. semicolorata) & - & $\cdot$ & $\cdot$ & - & 2.3 & 0.6 & - & - & - \\
\hline Ephemerella ignita Poda & - & - & $\cdot$ & - & - & - & 1.2 & 1.6 & 2.3 \\
\hline Ephemera danica Müller & - & - & - & - & - & - & - & 0.9 & - \\
\hline Caenis luctuosa (Burmeister) & - & $\cdot$ & $\cdot$ & - & - & - & - & - & - \\
\hline Chloroperla tripunctata Scop & - & 0.7 & 0.8 & - & - & - & - & - & - \\
\hline Leuctra sp. (gr. fusca) & - & 0.7 & 0.8 & - & - & - & 2.3 & 0.9 & 1.5 \\
\hline Euleuctra geniculata Steph & - & - & - & - & - & - & 1.2 & - & - \\
\hline Sysira fuscata Fbr & 0.6 & - & - & - & - & - & 0.6 & 0.6 & - \\
\hline Orectochilus villosus Müller & - & - & - & - & - & 0.5 & - & - & 0.7 \\
\hline Elmis aenea (Ph. Müller) (I) & - & - & - & - & - & - & 1.3 & 0.9 & 0.8 \\
\hline Esolus parallelepipedus (Ph. Müller) (l+i) & 0.5 & 0.7 & 0.5 & - & 1.7 & 1.0 & 3.0 & 5.6 & 8.2 \\
\hline Limnius volckmari Panzer (I) & - & 0.7 & - & - & - & - & - & - & - \\
\hline Psychomyia pusilla (Fabr.) & 2.7 & 2.1 & 3.2 & 9.2 & 13.8 & 3.8 & 3.5 & 2.1 & 1.6 \\
\hline Hydropsyche modesta Navas & 10.6 & 68.9 & 53.6 & 27.5 & 39.6 & 87.8 & 116.8 & 82.9 & 82.3 \\
\hline Hydropsyche contubernalis McL & 15.4 & 61.8 & 33.6 & 35.0 & 20.7 & 33.0 & 89.6 & 52.1 & 93.8 \\
\hline Hydropsyche exocellata Dufour & - & 1.5 & 2.2 & - & 1.7 & 3.6 & 1.9 & 2.1 & 3.0 \\
\hline Hydropsyche siltalaï Döhler & - & $\cdot$ & - & $\cdot$ & - & - & - & - & - \\
\hline Hydropsyche ornatula McL & - & - & - & - & - & - & 0.8 & - & - \\
\hline Hydropsyche pellucidula (Curt.) & - & - & 0.8 & - & - & - & - & 0.9 & - \\
\hline Cheumatopsyche lepida (Pict.) & - & - & - & - & - & - & - & - & - \\
\hline Athripsodes albifrons $L$. & - & $\cdot$ & - & 10.0 & 1.1 & 0.5 & 0.8 & 1.1 & 2.3 \\
\hline Ceraclea dissimilis (Steph.) & 1.6 & 23.0 & 13.4 & 5.9 & - & 0.6 & 6.3 & 22.4 & 12.3 \\
\hline Setodes punctatus Fabr. & 8.3 & 48.6 & 25.5 & 21.7 & 3.7 & - & 1.3 & 1.6 & 7.6 \\
\hline Hexatoma sp. & 1.6 & 0.7 & - & 10.9 & 6.3 & 0.6 & - & 2.3 & 0.8 \\
\hline Psychoda sp. & - & 1.1 & - & 5.0 & - & 0.5 & - & - & - \\
\hline Robackia sp. & 1.1 & - & 1.0 & - & 20.9 & - & - & - & - \\
\hline Hemerodromia sp. $(1+p)$ & 25.4 & 77.6 & 66.2 & 30.9 & 10.6 & - & 4.0 & - & 9.8 \\
\hline Total & 571.0 & 3118.5 & 1998.4 & 1763.4 & 660.3 & 845.5 & 2302.8 & 1905.4 & 1488.9 \\
\hline
\end{tabular}


Table 4. Decomposition of inertia (in \%) of the between-classes analyses performed on habitat $(\mathrm{H})$ and fauna $(\mathrm{F})$ matrices of a Rhône River reach. nPCA and $\mathrm{cPCA}=$ respectively normalized and centered Principal Component Analysis. Effects : 1 = duplicate of the samples; 2 = date of sampling (June and July 1982); 3 = spatial location of samples (9 locations) within the reach.

Tableau 4. Répartition de l'inertie (en pourcentage) des analyses entre points réalisées sur les matrices d'habitat $(\mathrm{H})$ et de faune $(\mathrm{F})$ de la portion étudiée. $\mathrm{nACP}$ et $\mathrm{cACP}=$ respectivement Analyse en Composantes Principales entre points normée et entre points centrée. Effets : 1 = répétition de l'échantillonnage; 2 = date d'échantillonnage (juin et juillet 1982); 3 = position des points d'échantillonnage (9) dans la portion étudiée.

\begin{tabular}{lccccc}
\hline & $\begin{array}{c}\text { Matrix } \\
\text { Analysis }\end{array}$ & \multicolumn{2}{c}{$\begin{array}{c}\text { Habitat } \\
\text { nPCA } \\
\text { Separate analysis }\end{array}$} & \multicolumn{2}{c}{$\begin{array}{c}\text { Fauna } \\
\text { cPCA } \\
\text { Separate analysis }\end{array}$} \\
\hline Effect & & Total & F1 + F2 & Total & F1 + F2 \\
1 - duplicate & & 1.8 & & 1.6 & \\
2 - date & 2.1 & & 21.4 & \\
3 - location & & 56.8 & 45.8 & 42.6 & 34.1 \\
Total explained effect & & 60.7 & & 65.6 & \\
Residual & 39.9 & & 34.4 & \\
Total & 100.0 & & 100.0 & \\
\hline
\end{tabular}

cially with the current velocity; $\mathrm{V}_{\mathrm{m}}$ was somewhat higher in June than in July (see Table 2), in relation to discharge variation between the two dates (796 vs $623 \mathrm{~m}^{3} \cdot \mathrm{s}^{-1}$, respectively). The most important changes in the fauna were due to seasonal development of some species, such as Hydra sp. in June, and Hydropsyche modesta and Setodes punctatus in July (see Table 3). However, the low variability attributed to the duplicate and date effects confirms the reliability of our sampling in the study of the spatial distribution of habitat and faunistic variables. Consequently, the analysis could be focused on only the spatial variations.

The between-locations normalised PCA performed on the habitat matrix $(\mathrm{H})$ explained $80.6 \%$ of the spatial variability on the first two axes (Fig. 3D). The F1 axis pointed out the opposition between the right and left hand sides of the channel (Fig. 3A). The F2 axis strongly highlighted ( $36.9 \%$ of the inertia), in its negative part, the originality of the middle of the channel. This analysis informs us that the vectors that represented the hydraulic parameters were fairly perpendicular to those linked to the size and quantity of mineral and organic material on the bed. This means that the substrate is independent of the present hydraulic conditions. The faunistic table (F) was analysed by a between-locations centered PCA (Fig. 3B \& E). The F1 axis indicates the uniqueness of the right hand side of the channel, compared with the middle and left hand side. The F2 axis was lower than for the habitat (16.1 versus $36.9 \%$ of the inertia) and opposed only the left hand side to the middle of the channel. The species positions on this $\mathrm{F} 1 \mathrm{XF} 2$ plane were only slightly modified in the co-inertia analysis and will be presented with this latter analysis.

\subsection{Habitat-fauna relationships in space}

The spatial co-structures of habitat (matrix $\mathrm{H}$ ) and fauna (matrix F) are shown by the between-classes PCA, in which the 9 classes were the 9 sampling locations. The co-inertia analysis between these two between-classes analyses revealed the similarities of the two spatial distribution structures (Fig. 4). Its main variability $(80.1 \%)$ was expressed on the $\mathrm{F} 1$ axis. Only $17.1 \%$ was expressed on the F2 axis (Fig. 4A). The F1 and $\mathrm{F} 2$ axes of co-inertia were a combination of the two habitat axes and they were very close to the F1 and F2 axes of the basic fauna analysis (Fig. 4B). The correlation of the two structures was high $(0.931$ on F1 and 0.897 on F2). Among the $45.8 \%$ of the total variability dealing with spatial habitat variations within the reach expressed on the two first axes F1 and F2 of the habitat analysis (see Table 4), $40.7 \%$ were still preserved on the axis F1 and F2 of the co-inertia analysis. For the fauna variability, these percentages were respectively 34.1 and 33.3. This provides evidence that a very significant part of the two between-locations habitat and fauna structures was preserved in the co-inertia analysis and that the F1 x F2 planes are true pictures of these co-structures. 


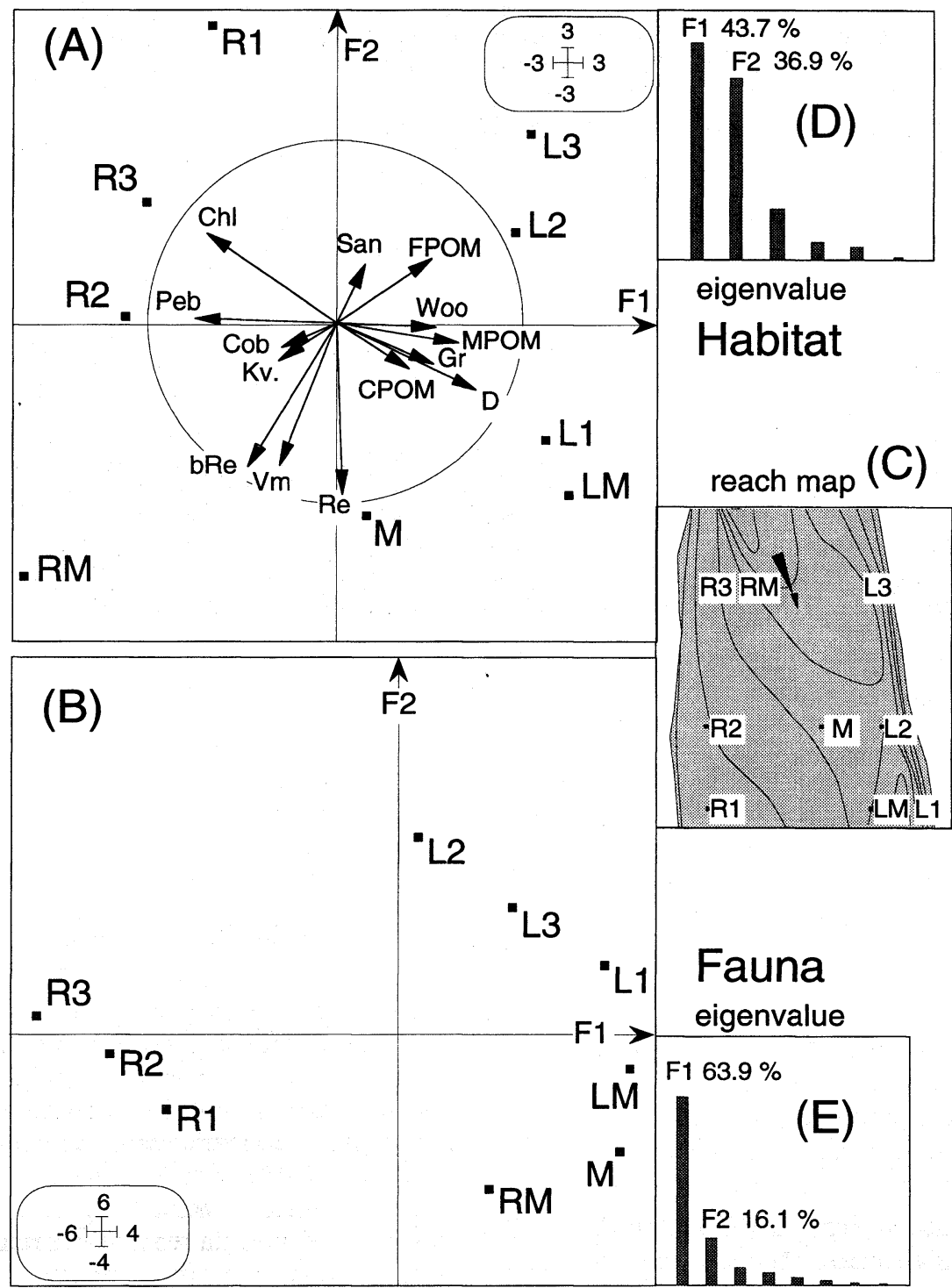

Fig. 3. Between-classes ( 9 locations) Principal Component Analyses of habitat table $\mathbf{H}$ (normalised analysis) and fauna table F (centered analysis). (A) and (B): Ordination diagrams of the 9 locations, with their position in the reach (C). Insert in the habitat plane (A) : circle of correlation of the 14 habitat variables (code : see Tables 1\&2). (D) and (E) : eigenvalues of the two first factors in each analysis.

Fig. 3. Analyse en composantes principales inter-classes (9 points) du tableau habitat $(\mathrm{H}$; analyse normée) et du tableau faune ( $\mathrm{F}$; analyse centrée). (A et B) Cartes factorielles des 9 points, avec rappel de leur position sur la portion de chenal étudiée (C). Sur la carte factorielle habitat (A) : projection du cercle des corrélations des 14 variables d'habitat (voir codes Tableaux $1 \& 2$ ). (D) Valeurs propres des deux premiers facteurs de chaque analyse. 

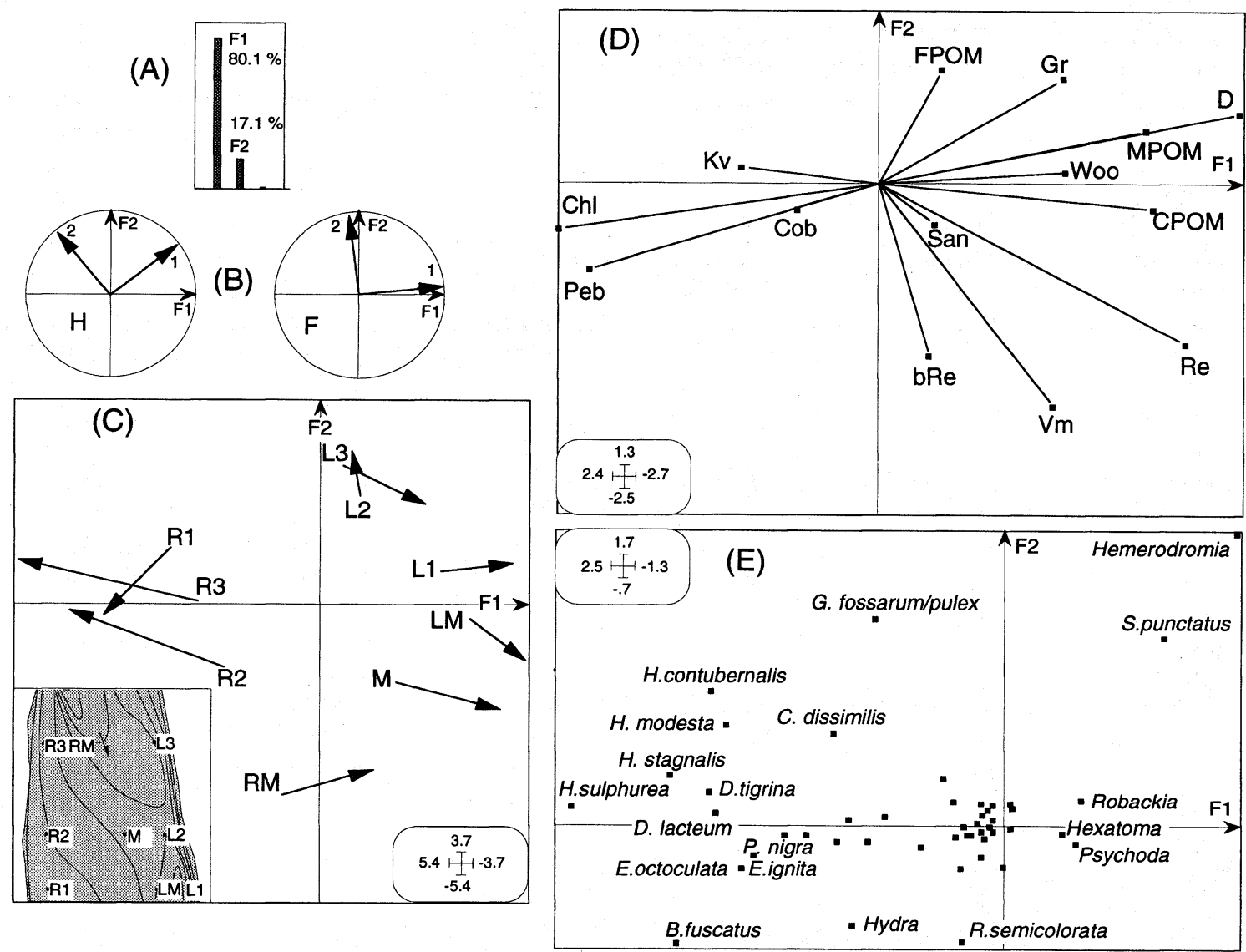

Fig. 4. Results of the co-inertia analysis of the 14 habitat variables (matrix H, between-locations normalised PCA) and 47 species (matrix F, between-locations centered PCA) in 9 locations of the Rhône River reach. F1 x F2 planes. (A) Eigenvalues of the co-inertia analysis. (B) Projection of the axes of the separate analyses of the matrices $\mathrm{H}$ and $\mathrm{F}$ (full arrows) on the co-inertia plane (axes in broken arrows). (C) Ordination diagram of the 9 locations by means of the habitat variables (beginning of the arrows) and by means of the species (end of the arrows) in the co-inertia plane. Insert: position of the 9 locations in the reach (see Fig. 1D). (D) Ordination diagram of the 14 habitat variables in the co-inertia (code : see Table 2). (E) Ordination diagram of the 47 species in the coinertia (black squares), only the names of the most relevant species are indicated (see text and Fig. 5).

Fig. 4. Résultats de l'analyse de co-inertie des 14 variables d'habitat (matrice H, ACP entre-points normalisée) et des 47 taxons (matrice F, ACP entre-points centrée) des 9 points échantillonnés. Plan F1 X F2. (A) Valeurs propres de l'analyse de co-inertie. (B) Projection des axes des analyses séparées des matrices $\mathrm{H}$ et $\mathrm{F}$ (flèches en trait épais) sur le plan de co-inertie (axes en trait mince). (C) Projection des 9 points représentés par les variables d'habitats (début des flèches) et par les taxons (extrémité des flèches) dans le plan de co-inertie avec rappel (encadré) de la position des points sur la portion de chenal étudiée. (D) Projection des 14 variables dans le plan de co-inertie (voir codes Tableaux 1\&2). (E) Projection des 47 taxons (carrés noirs) dans le plan de co-inertie; seuls sont indiqués les noms des taxons les plus significatifs (voir texte et Fig. 5).

The uniqueness of the right hand side of the channel was the main structure, which appeared on the negative part of the F1 axis, even more strongly for the fauna (end of the arrows on the Fig. 4C) than for habitat (beginning of the arrows). The locations of the left hand side and middle of the channel were positioned in the positive part of the F1 axis. These two parts were well se- parated on the $\mathrm{F} 2$ axis, but the differences were slight, with only $17.1 \%$ of the co-inertia variability (Fig. 4A).

The right hand side of the channel was characterized (Fig. 4D) by high quantities of chlorophyll a (from algae development), coarse sediments (especially pebbles) and a rather high bottom heterogeneity $\left(\mathrm{k}_{\mathrm{v}}\right)$; water depth, quantities of organic materials and the hy- 
draulic parameters, especially the Reynolds number $(\mathrm{Re})$, were rather low. The left hand side of the channel had somewhat finer organic or mineral materials, while the middle of the channel (mainly the locations RM and $M$ ) had rather high values of the hydraulic parameters (Fig. 4D). The maximized correlation of the two habitat axes with the two faunistic axes (Fig. 4B) suggested that the major fauna variability was linked both to the substrate variables (F1 habitat) and, to a lesser extent, to the hydraulic variables ( $\mathrm{F} 2$ habitat). That means that each of these two types of variables, which were rather independent of each other in the habitat structure, did not have a separate effect on a specific part of the fauna, but operated together upon the whole fauna. In fact, the most organizing habitat variables (the longest vectors on the Figure 4D) were the water depth (D), the Reynolds number (Re, which is regulated by the water depth), and the growth of periphyton represented here by the chlorophyll a $(\mathrm{Chl})$ growing on the coarse mineral substrates (Peb). The faunistic importance of all the other variables, representative of the mineral and organic substrate pattern, was smaller (shorter vectors on the Fig. 4D); the most important were the medium and coarse organic particulate material (MPOM and CPOM).

The fauna linked with these structures is presented in figure 4E. Firstly, nearly one third of all the species was grouped near the centre of the factorial map. This means that they were rather uniformly distributed on the 9 sampling locations. Secondly most of the other species were on the negative end of the F1 axis. This suggested that there was a mass effect, with larger faunistic densities to the right hand side of the channel (locations R1, R2, R3 and RM). Several species were clearly more abundant in this right hand side of the channel (see Table 3). All Tricladida and Achaeta were concerned, as well as the Trichoptera Hydropsyche contubernalis and $H$. modesta, the Ephemeroptera Heptagenia sulphurea and Baetis fuscatus. Only one species, the Trichoptera Setodes punctatus, and the four species of Diptera, positioned in the upper right quadrat of the $\mathrm{F} 1 \times \mathrm{F} 2$ plane, were consequently more abundant in the left hand side of the channel. No species was characteristic of the middle of the channel. The Ephemeroptera Rhithrogena semicolorata and the Hydraria Hydra sp. are nevertheless in the nearest position, in correspondence with the location RM.

These results could be visualized by the projections of the most characteristic variables on the locations positioned on the reach map (Fig. 5). Firstly, the spatial distribution of the F1 and F2 scores of the co-inertia analysis (Fig. 5A), functions that summarized the spa- tial structures of habitat and fauna, could be compared. There was a high correspondence between habitat and fauna distribution. A transversal gradient highlighted by the depth was particularly evident with the F1 scores. The distribution of some parameters, such as coarse sediments and chlorophyll a, and species that were relevant on the F1 axis of the co-inertia (Fig. 5B), emphazised the habitat uniqueness of the right hand side of the channel and its faunistic specificity. Some species were almost confined to this area, or extended to the central channel (the Achaeta Erpobdella octoculata, the Ephemeroptera Baetis fuscatus and Ephemerella ignita) while others (such as the Tricladida Dugesia tigrina, the Ephemeroptera Heptagena sulphurea and the Trichoptera Hydropsyche contubernalis) mainly avoided the middle of the channel and preferred locations near the banks, especially the right hand bank. The left hand side of the channel was only prefered by the Trichoptera Setodes punctatus and the four species of Diptera (Hemerodromia sp., Robackia sp., Hexatoma sp. and Psychoda sp.) (Fig. 5B). F2 (see Fig. 4), demonstrated the originality of some locations in the middle of the channel (RM, M) versus the left hand side. The parameters linked to F2 axis are less clearly distributed; if the current velocity is stronger in the three locations of the middle of the channel, the spatial preference of the Ephemeroptera Rhithrogena semicolorata was not restricted to this area (Fig. 5B). The faunistic poverty of the middle of the channel, in abundance as well as in species richness, contrasted with the near bank areas (Fig. 5A).

\section{Discussion}

\subsection{An inherited bottom habitat pattern}

A transversal asymmetry of the channel was clearly expressed in the results, for both habitat and fauna, with a particular originality of the right hand side and, to a lesser degree, of the left hand side versus the middle of the channel.

The relationship between hydraulic parameters and mineral or organic substrate is usually organized by the eroding and depositing role of the hydraulic forces (Cummins et al. 1966, Hynes 1970, Resh \& Rosenberg 1984). In the low current areas of the St Laurence $\mathrm{Ri}$ ver, Vincent (1981) found that depth and current velocity were strongly correlated, but rather independent of the substratum size. In the present study, there was an independence between the spatial distribution of hydraulic features and the composition of mineral and organic sediments (Figs 3A and 5B). The most rapid currents were not associated with the coarsest sediments (in the right hand side of the channel) and the transver- 
(A) global parameters
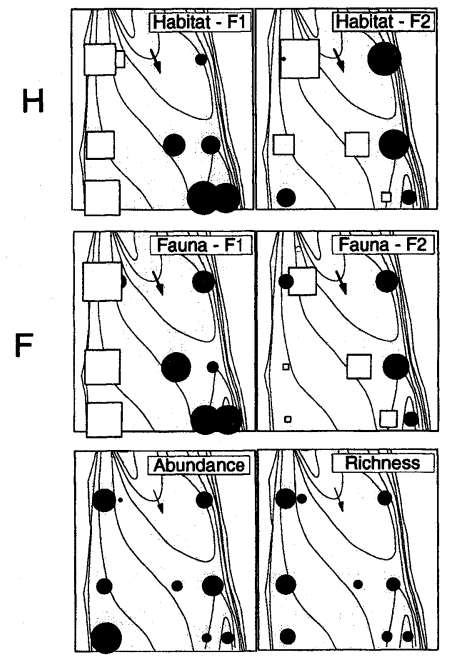

(B) Variables right hand side preferences

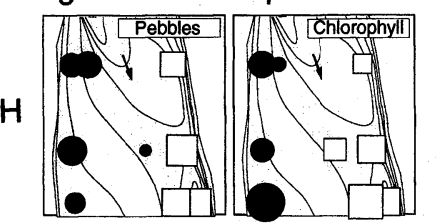

F
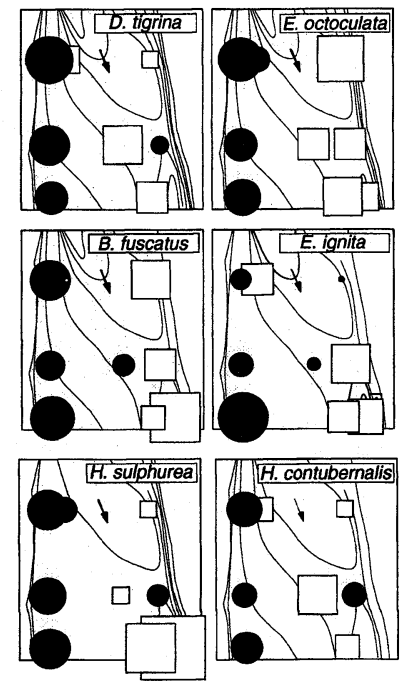

left hand side or middle preferences
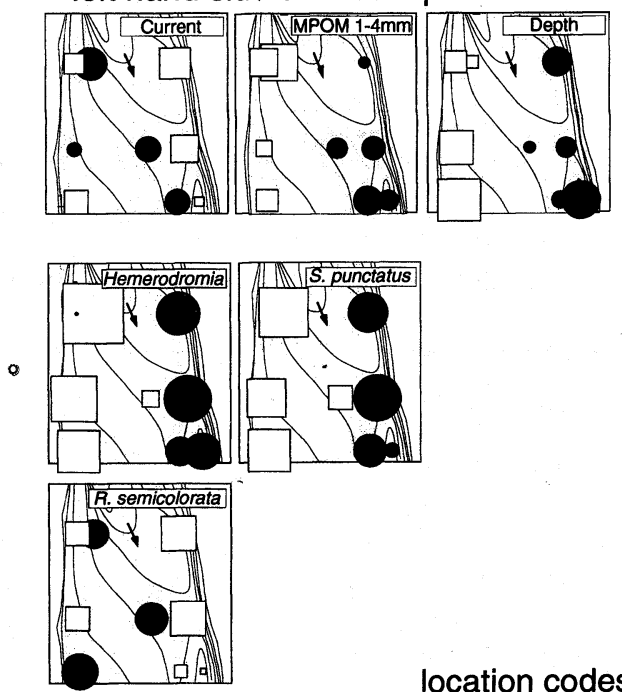

location codes

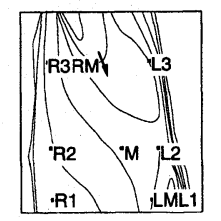

Fig. 5. Distribution of some variables in the 9 sampling locations of the channel within the Rhône River reach. The area of squares and circles are proportional to the values of the variables at the location. (A) The global parameters are i) the F1 and F2 scores of the habitat (between-locations normalized PCA) and fauna (between-locations centered PCA) analyses in the plane of the co-inertia analysis (circles = positive scores, squares = negative scores); ii) abundance (mean number per 10 liters of sediment, from 493.7 in RM to 3048.7 in R1) and richness (mean number of species per sample, from 15.5 in LM to 33.5 in R2). (B) The habitat (H) and fauna (F) variables are chosen as the most relevant on the F1 or F2 axes of the co-inertia analysis; they are centered : circles $=$ values $>$ general mean, and squares $=$ values $<$ general mean.

Fig. 5. Distribution de quelques variables sur les 9 points échantillonnés dans la portion de chenal étudiée. La surface des carrés et des cercles est proportionnelle à la valeur de la variable en ce point. (A) Les paramètres globaux sont : i) les coordonnées des points habitat (entre-points sur ACP normalisée) et des points faune (entre-points sur ACP centrée) sur F1 et F2 dans le plan de l'analyse de co-inertie (cercle noir = coordonnée positive, carré blanc = coordonnée négative); ii) abondance (nombre moyen d'organismes pour 10 litres de sédiments, de 493,7 en RM à 3048,7 en R1) et richesse (nombre moyen de taxons par échantillon, de 15,5 en LM à 33,5 en R2). (B) Les variables d'habitats (H) et de faune $(F)$ sont choisies en fonction de leur pertinence sur les axes F1 et F2 de l'analyse de co-inertie; ils sont centrés : cercles = valeur > moyenne générale, et carré = valeur < à la moyenne générale.

se pattern was asymmetric, although the reach was situated in an almost straight length of the course (Fig. 1). The present sediment distribution could not have been structured by the present current distribution. Three causes can explain this situation.

i) The bottom sediments were organized during earlier spates and the presently observed situation was inherited from these spate depositions. Lamberti \& Resh (1979) and Statzner et al. (1988) have already obser- ved that the size distribution of substratum within a reach often reflects a past spate rather than the present flow conditions. The transporting (shearing) capacity of the river under the conditions measured in June and July 1982 was unable to modify the bottom distribution of sediments. Moreover the reach is under the influence of the Jons dam (Fig. 1) which regulates the water level (no variations greater than 0.5 meters). Nevertheless, during floods or spates exceeding 
$1000 \mathrm{~m}^{3} \cdot \mathrm{s}^{-1}$, flow is diverted into the Miribel canal (Fig. 1B, C) located on the right hand side of the studied reach. Consequently this may be responsible for the coarser sediments in this area.

ii) The present situation also seems to be inherited from embankments built in 1885 along this reach of the Rhône river (see above and Fig. 1). Flow was pushed towards the right hand bank by the Villette embankment and its erosion power led to a degradation near the Chambarin embankment (up to 8 meters deep). The flow was then pushed back towards the Bianne embankment near the left hand bank where further degradation occurred (nearly 5 meters deep). The studied reach was located between the former left hand bank degradation and the right hand bank aggradation areas (Fig. 1). The resulting bottom pattern is now preserved, because, since later flow regulations, the river has lost its flow competence. This transverse pattern of the reach is similar to the riffle (right hand side) - pool (left hand side) sequence of streams.

iii) The settling of the bottom substrate in this reach due to an inherited situation has been further reinforced by the general armouring and bonding of the mineral coarse particles in the large rivers, particularly in this reach of the Rhône River (Gordon et al. 1992). This armouring prevents all changes in the superficial coarse bottom, except for the temporary depositing and movement of fine sediments and organic particles on the surface of the coarser armoured substrate, which acts as a solid surface. These deposits explain why some dredged samples contained only sand (Tachet et al . 1991).

In conclusion, the asymmetric spatial pattern of the benthic habitats in the studied reach were inherited and different from the standard pattern of a coarse rapid channel and a gradient to finer and more heterogeneous sediments in the slower currents towards the banks.

\subsection{What habitat variables influence the microdis- tribution pattern of the macroinvertebrate fauna?}

The relative spatial independence of the hydraulic and other habitat parameters within the reach means that the relationship between the fauna and these sets of parameters could have been considered independently. In fact, the co-structure between habitat and fauna was high, but between all the habitat conditions, without distinct species clearly linked to hydraulic variables (Fig. 4D \& E). Most studies (Minshall \& Minshall 1977, Milner et al. 1981) have stated that riffles, with their higher current velocities, support higher densities of Ephemeroptera and Trichoptera than pools, but few taxa appear to be restricted to either one in the same river system. In our study, depth was the main structuring habitat parameter for the fauna (Fig. 6). Egglishaw (1969) and Lapchin (1977) have noted the effect of water depth on stream macroinvertebrates. The relationships are more complicated in large rivers. In the Main River no clear relationship appeared between depth and macroinvertebrates (Schleuter \& Tittizer 1988). For Beckett et al. (1983) in the Mississippi River, the macrodistribution is influenced mainly by both substrate and current velocity. Current influences macrodistribution in lowlands streams while substrate particle size and food supply are the most important factors influencing microdistribution (Tolkamp 1982, Cummins \& Lauff 1969). More recently, Lancaster and Hildrew (1993) observed that the macroinvertebrate microdistribution reflects some «long term shifts in response to average or seasonal flow conditions».

In the studied Rhône reach, water depth has been inherited from earlier conditions, natural spates and management, which has also led to the present bottom substratum pattern (Fig. 6). These two inherited variables, water depth and presence of coarse sediments (pebbles) on the right hand side of the channel, are now two major fauna organizing factors in the reach. The current velocity is regulated within the reach mainly by the bank distance and up- and downstream course morphology and regulation (see above), and it is rather independent of depth. The hydraulic parameters (Reynolds numbers), regulated by depth and current velocity, act upon macroinvertebrate microdistribution directly or by means of the deposition of fine elements (sand, fine particulate organic material), or by the turbulence intensity, which also influences periphyton development. Effectively, Quinn \& Mickey (1994) showed that the benthic invertebrate microdistribution in two New Zealand rivers was most strongly correlated with the boundary Reynolds number (bRe), but in the present study the habitat parameters that were most correlated with the macrobenthos were the coarse elements of the substrate (pebbles), due to both their roughness thus offering many microspaces for the invertebrates and their surface area which favours periphyton development (chlorophyll a). The fine sediments, particularly the particulate organic material, seemed somewhat less important for the fauna of this reach.

For the macroinvertebrates, the least favourable areas were firstly the middle of the channel, with higher current velocities and shear stresses, and secondly the left deep hand side, with high Reynolds numbers. Both are richer in intra-sediment particulate ma- 


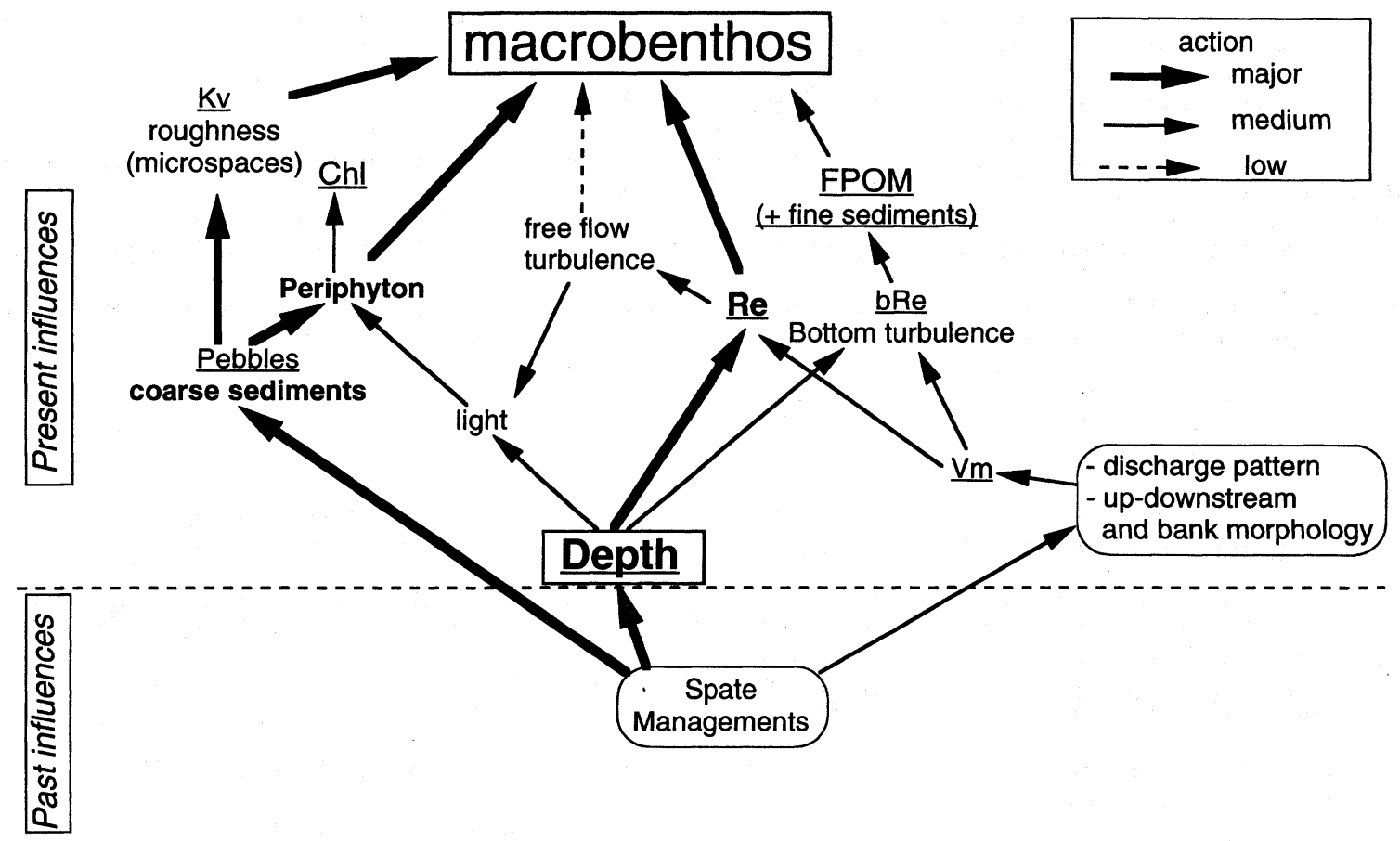

Fig. 6. Past and present actions of habitat variables on macrobenthos within a Rhône River reach (in bold : the most significant variables for macroinvertebrates; underlined : measured or evaluated variables).

Fig. 6. Actions présentes et passées des variables d'habitat sur le macrobenthos dans la portion de chenal étudiée (en caractères gras : variables les plus significatives pour les invertébrés; mots soulignés : variables mesurées ou estimées).

terials (Fig. 4). Usually it is the middle of the channel, the furthest from the banks, that has the poorest fauna (Ferencz 1974 a,b, Anderson \& Day 1986). The most favourable area in this study was the right hand side, with lower hydraulicity and forces but coarser sediments. These two conditions which favour the abundance and the species richness of the macrobenthos are not usually met together.

\section{Acknowledgments}

We would like to thank Bernhardt Statzner for his comments on an earlier version of the manuscript, Daniel Chessel for his advice concerning the data analyses and Glyn Thoiron for linguistic advice.

\section{References}

Andersen T. \& Day D.M. 1986. - Predictive quality of macroinvertebrate habitat associations in lower navigation pools of the Mississipi River. Hydrobiologia, 136 : 101-112.

Beckett D.C., Bingham C.R. \& Sanders L.G. 1983. - Benthic macroinvertebrates of selected habitats of the Lower Mississippi River. J. Freshwat. Ecol., $2: 247-261$.
Berly A. 1989. - Distribution spatio-temporelle des peuplements macrobenthiques prélevés par dragage dans une station du HautRhône. Thèse Doctorat, Univ. Lyon I : 309 p.

Boillot G. 1964. - Géologie de la Manche occidentale. Fonds rocheux, dépôts quaternaires, sédiments actuels. Ann. de l'Inst. océanogr., 42 : 1-219.

Carrel G., Barthelemy D., Auda Y. \& Chessel D. 1986. - Approche graphique de l'analyse en composantes principales normée : utilisation en hydrobiologie. Acta Ecol., Ecol.Gener. 7 : 189-203.

Cellot B. \& Bournaud M. 1984. - Structure et fonctionnement des écosystèmes du Haut-Rhône français. 39. Dynamique saisonnière des mouvements de l'eau et des particules en suspension dans un fleuve. Verh. Internat. Verein. Limnol., 22 : 2002-2008.

Chessel D. \& Dolédec S. 1993. - ADE Version 3.6 : HyperCard (C Stacks and QuickBasic MicroSoft (c) Programme library for the Analysis of Environmental Data. Manuel d'utilisation. 8 fascicules. URA CNRS 1451, Université Lyon 1, 69622 Villeurbanne cedex : $750 \mathrm{p}$.

Chessel D. \& Mercier P. 1993. - Couplage de triplets statistiques et liaisons espèces-environement. In : Biométrie et Environment. Lebreton J.D. \& Asselain B. (Eds.) Masson, Paris: 15-44.

Cummins K.W. \& Lauff G.H. 1969. - The influence of substrate particle size on the microdistribution of stream macrobenthos. Hydrobiologia, 34 : 145-181. 
Cummins K.W., Tryon C.A. \& Hartman R.T. 1966. - Organismsubstrate relationships in streams. Pymatuning Symposia in Ecology, Univ. Pittsburgh, 4 : 145 p.

Dolédec S. \& Chessel D. 1989. - Rythmes saisonniers et composantes stationnelles en milieu aquatique II- Prise en compte et élimination d'effets dans un tableau faunistique. Acta Ecol., Ecol. Gener., $10: 207-232$.

Dolédec S. \& Chessel D. 1991. - Recent developments in linear Ordination methods for environmental Sciences. Adv. in Ecol., 1 : 133-155.

Dolédec S. \& Chessel D. 1994. - Coinertia analysis : an alternative method for studying species-environment relationships. Freshwater Biol., $31: 277-293$.

Dolédec S. \& Statzner B. 1994. - Theorical habitat templet, species traits, and species richness: 548 plant and animal species in the Upper Rhône River and its floodplain. Freshwater Biol., 31 : 523538.

Egglishaw H.J. 1969. - The distribution of benthic invertebrates on substrata in fast-flowing streams. J. Anim. Ecol., 38 : 19-33.

Ferencz M. 1974a. - Zoobenthic studies on the lower reaches of the Tisza and Maros. Acta Biologica Szeged, 20 : 143-155.

Ferencz M. 1974b. - Data on the horizontal and vertical distributions of the zoobenthos of the Tisza. Tiscia (Szeged), $9: 65-69$.

Gabriel K.R. 1971. - The biplot graphical display of matrices with application to principal component analysis. Biometrika, 58 : 453467.

Gaschignard O. \& El Hamdi M. 1984. — La granulométrie du sédiment et l'évolution du benthos dans un bras vif du Rhône. Rev. fr. Sci. Eau, 3 : 279-293.

Gaschignard O., Persat H. \& Chessel D. 1983. - Répartition transversale des macroinvertébrés benthiques dans un bras du Rhône. Hydrobiologia, 106 : 209-215.

Gordon N.D., McMahon T.A. \& Finlayson B.L. 1992. - Stream hydrology. An introduction for ecologists. J. Wiley \& Sons, New York : $526 \mathrm{p}$.

Gower J.C. 1967. - Multivariate analysis and multivariate geometry. The statistician, $17: 13-28$.

Hynes H.B.N. 1970. - The ecology of running waters. Liverpool : University Press, Liverpool : 555 p.

Lamberti G.A. \& Resh V.H. 1979. - Substrate relationship, spatial distribution patterns, and sampling variability in stream caddisfly population. Environ. Entomol., $8: 561-567$.

Lancaster J. \& Hildrew A.G. 1993. - Flow refugia and the microdistribution of lotic macroinvertebrates. J. N. Am. Benthol. Soc., $12: 385-393$

Lapchin L. 1977. - Microrépartition des invertébrés benthiques dans deux ruisseaux à Salmonides de Bretagne. Ann. Hydrobiol., $8: 319-332$.

Lebreton J.D., Sabatier R., Banco G. \& Bacou A.M. 1991. - Principal component and correspondence analyses with respect to instrumental variables: an overview of their role in studies of structure - activity and species - environment relationships. In : Applied Multivariate analysis in SAR and environmental studies. J. Devillers \& W. Karcher. (Ed.s) ECSC, EEC, EAEC, Brussels and Luxembourg: 85-114.

Lorenzen C.J. 1967. - Determination of chlorophyll and phaeopigments spectrophotometric equations. Limnol. Oceanogr., 12 : 343-346.
Milner N.J., Scullion J., Carling P.A. \& Crisp D.T. 1981. — The effects of discharge on sediment dynamics and consequent effects on invertebrates and salmonids in upland rivers. Adv. appl. Biol., $6: 153-220$

Minshall G.W. \& Minshall G.W. 1977. - Microdistribution of benthic invertebrates in a Rocky Mountain (USA) stream. Hydrobiologia, $55: 231-240$.

Perrin J.F. \& Roux L. 1978. - Structure et fonctionnement des écosystèmes du Haut-Rhône français. 6. La macrofaune benthique du fleuve. Verh. Internat. Verein. Limnol., 20 : 1494-1502.

Quinn J. M. \& Hickey C.W. 1994. - Hydraulic parameters and benthic invertebrate distribution in two gravel-bed New Zealand rivers. Freshwater Biol., 32 : 489-500.

Resh V.H. \& Rosenberg D.M. 1984. - The ecology of aquatic insects. Praeger, New York: 625 p.

Schleuter von A. \& Tittizer T. 1988. - Die Makroinvertebratenbesiedlung des Mains in Abhängigkeit von der Gewässertiefe und der Korngrösse des Substrates. Arch. Hydrobiol., 113 : 133-151.

Smith I.R. 1975. - Turbulences in lakes and rivers. Freshwater biological Association, scientific Publication 29, Ambleside, U.K.

Sopp E. 1983. - Verteilung des Makrozoobenthons im Querprofil des Rheins bei der Loreley. Verhandl. Gesells. Ökol., $10: 279$ 285 .

Statzner B., Gore J.A. \& Resh V.H. 1988. - Hydraulic stream ecology: Observed patterns and potential applications. J. N. Am. Benthol. Soc., $7: 307-360$

Statzner B., Kohman F. \& Hildrew A.G. 1991. - Calibration of FST-hemispheres against bottom shear stress in a laboratory flume. Freshwater Biol., 26 : 227-231.

Strickland J.D.M. \& Parsons T.R. 1972. - A practical handbook of seawater analysis. Bull.. Fish. Res. Board Can., $167: 2$ nd Ed.: 310 p.

Tachet H., Bournaud M., Berly A. \& Cellot B. 1991. - Le macrobenthos d'un fleuve et son milieu : interactions spatio-temporelles à l'échelle d'une station. Bull. Ecol., 22 : 187-194.

Ter Braak C.J.F. 1983. - Principal components biplots and alpha and beta diversity. Ecology, 64 : 454-462.

Tolkamp H.H. 1982. - Microdistribution of macroinvertebrates in lowland streams. Hydrobiol. Bull., 16 : 133-148.

Vincent B. 1981. - Profondeur, vase et courant, facteurs de microrépartition transversale du benthos dans l'estuaire d'eau douce du Saint-Laurent (Québec). Can. J. Zool., 59 : 2297-2305.

Vincent B. \& Vaillancourt G. 1978. - Les groupements benthiques du fleuve Saint-Laurent près des centrales nucléaires de Gentilly (Québec). Can. J. Zool., 56 : 1585-1592.

Ward J.V. 1988. - The four-dimensional nature of lotic ecosystems. J. N. Am. Benthol. Soc., $8: 2-8$.

Ward J.V. 1989. - Riverine-wetland interactions. In : Freshwater wetlands and wildlife. DOE symp. Ser.N ${ }^{\circ} 61$,Sharitz R.R. \& Gibbons J.W. (Eds.), Oak Ridge, Tennessee: 385-400.

Wells F.C. \& Demas C.R. 1979. - Benthic invertebrates of the Lower Mississippi River. Water Resour. Bull., 15 : 1565-1577.

Winget R.N. 1985. - Methods of determining successful reclamation of stream ecosystems. In : The restoration of rivers and streams. Gore J.A. (Ed.), Butterworth Publishers, Stoneham, Massachusetts :165-192.

Zhadin V.I. \& Gerd S.V. 1961. - Fauna and flora of the rivers, lakes and reservoirs of the U.S.S.R. Israel Program for Scientific Translations, Jerusalem, 1970: $626 \mathrm{p}$. 